\title{
Analysis of oral health conditions and risk factors for dental caries in patients with sickle cell disease
}

Condições de saúde bucal e análise de fatores de risco de cárie dentária de pacientes portadores de doença falciforme

\author{
Michelle Leão Bittencourt Brandão MEDEIROS \\ (i) ORCID iD 0000-0002-3639-4529 \\ Luciana Lira MENDES² \\ (iD) ORCID iD 0000-0002-8257-0466 \\ Sergio Luiz Pereira LOPES ${ }^{2}$ \\ (iD) ORCID iD 0000-0002-0068-7020 \\ Elifabiana Leite ARAÚJO² \\ (iD) ORCID iD 0000-0001-6449-9195 \\ Izabel Cristina Gomes da SILVA ${ }^{1}$ \\ (iD) ORCID iD 0000-0002-6098-318X \\ Emerson Nicácio MEDEIROS 3 \\ (i) ORCID iD 0000-0003-2908-4546 \\ Tayguara Cerqueira CAVALCANTI ${ }^{2}$ \\ (iD) ORCID iD 0000-0002-3066-476X \\ Natanael Barbosa dos SANTOS 1 \\ (ii) ORCID iD 0000-0003-1811-2927
}

\section{ABSTRACT}

Objective

To analyze the oral health conditions and risk factors for caries in patients with sickle cell disease.

\section{Methods}

An observational, cross-sectional study was conducted in the clinic of the Association of Persons with Hemoglobinopathies of Alagoas, in the city of Maceió-AL, Brazil. The sample composed of 43 patients were included by census sampling. The ICDAS/DMFT/dmf-t caries indices were used, and simplified oral hygiene, salivary flow and buffer capacity tests were performed. Patients were interviewed to check their level of knowledge about oral hygiene and diet. Spearman correlation and ANOVA statistical tests were applied $(p<0.05)$.

\section{Results}

The mean DMFT was 15.49 \pm 4.43 ; oral hygiene regular (IHOS=2.22 \pm 0.18 ); mean salivary flow 0.92 \pm 0.26 , and mean buffer capacity 4.60 \pm 0.32 . Correlation was found between salivary flow and buffer capacity $(p=0.009)$. Patients with the highest caries prevalence, in the age-ranges 6 to 12 , and 20 to 26 years, had the lowest buffer capacity values $(p=0.04)$. Interviews showed that $58 \%$ did not use dental floss, $88 \%$ consumed cariogenic snacks, 100\% reported never having received guidance from dentists about the cariogenic potential of foods and $60 \%$ reported the use of anticholinergic medications to reduce drooling (Trama/® and morphine) during pain crises.

\section{Conclusion}

These patients presented extremely high caries prevalence, with predominance of carious teeth. The salivary parameters analyzed and level of knowledge about oral hygiene and cariogenic diet presented, showed that patients with sickle cell disease belonged to a group with risk for development of dental caries.

Indexing terms: Dental caries. Diet. Oral hygiene. Saliva. Sickle cell anemia.

\section{RESUMO}

\section{Objetivo}

Analisar as condições de saúde bucal e fatores de risco de cárie de pacientes com doença falciforme.

\section{Métodos}

A pesquisa observacional e transversal foi realizada na Associação de Pessoas com Hemoglobinopatias de Alagoas situada na cidade de Maceió-AL. Amostra composta por 43 pacientes incluídos por amostragem censitária. Foram utilizados os índices de cárie ICDAS/CPOD/ceod e de higiene oral simplificado, testes de fluxo salivar e capacidade tampão. Os pacientes foram entrevistados para a verificação do nível de

\footnotetext{
${ }^{1}$ Centro Universitário CESMAC, Programa de Pós-Graduação em Pesquisa em Saúde. Rua Cônego Machado, 918, Farol, 57051-160, Maceió, AL, Brasil. Correspondência para / Correspondence to: MLBB MEDEIROS. E-mail: <michelle-eao@hotmail.com>

${ }^{2}$ Centro Universitário CESMAC, Graduação em Odontologia. Maceió, AL, Brasil.

${ }^{3}$ Associação Brasileira de Odontologia. Maceió, AL, Brasil.

\section{$\checkmark v$}

Como citar este artigo / How to cite this article

Medeiros MLBB, Mendes LL, Lopes SLP, Araújo EF, Silva IZG, Medeiros, et al. Analysis of oral health conditions and risk factors for dental caries in patients with sickle cell disease. RGO, Rev Gaúch Odontol. 2018;66(3):232-238. http://dx.doi.org/10.1590/1981-863720180003000063408
} 
conhecimento sobre higiene bucal e dieta. Foram aplicados os testes de correlação de Spearman e ANOVA $(p<0,05)$.

\section{Resultados}

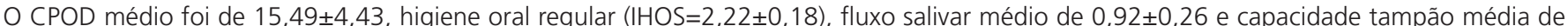
$4,60 \pm 0,32$. Existiu correlação entre o fluxo salivar e capacidade tampão $(p=0,009)$. Os pacientes com maiores prevalências de cárie, nas faixas etárias de 6 a 12 anos e 20 a 26 anos, possuíam os mais baixos valores de capacidade tampão $(p=0,04)$. A entrevista mostrou que $58 \%$ não utilizavam fio dental, $88 \%$ lanchavam alimentos cariogênicos, $100 \%$ relataram nunca ter recebido orientações do cirurgião dentista sobre o potencial cariogênico dos alimentos e $60 \%$ relataram que utilizavam medicamentos redutores de salivação (Tramal ${ }^{\circledR}$ e morfina) durante as crises álgicas.

\section{Conclusão}

Os pacientes apresentaram uma prevalência de cárie muito alta, com a predominância de dentes cariados. Os parâmetros salivares analisados e o nível de conhecimento, sobre higiene bucal e dieta cariogênica apresentados, mostraram que pacientes com doença falciforme pertencem a um grupo de risco de desenvolvimento de cárie dentária.

Termos de indexação: Cárie dentária. Dieta. Higiene buccal. Saliva. Anemia falciforme.

\section{INTRODUCTION}

Sickle cell disease is a genetic hemoglobinopathy characterized by the presence of an abnormal molecule of hemoglobin, called hemoglobin S (HbS) [1] When present in homozygous form, HbS forms polymers which, when deoxygenated change the red blood cell shape from biconcave discoid to sickle [2,3], giving rise to sickle cell anemia, which receives this denomination due to the format acquired by these red blood cells. It is the most common genetic disorder around the world, with an estimated 70 million people carrying the sickle cell gene [4] and it is also the most prevalent hereditary hematological disease in Brazil [4-8], with an estimate that more than 2 million people carry the HbS gene and more than 8000 present a severe homozygous form [8]. This type of anemia was originally recognized and described by Herrick in 1910 $[9,10]$. It is an incurable chronic disease which brings suffering to patients and their families [2]. Its treatment involves medical, dental, genetic and psychosocial factors [11].

Sickle cell disease clinical manifestations derive directly from the HbS molecular abnormality along with chronic inflammatory manifestations [1]. The disease is characterized by two abnormal alleles which are shown as: chronic hemolytic anemia, recurrent pain crises, bacterial infections, gradual tissue deterioration and organic function, which may lead to a shortened life expectancy [6-8], mainly due to to multiple organ failure [1].

Several interchangable factors are responsible for the chronic inflammatory state in sickle cell disease patients [1]. Except for bone marrow transplantation, the treatment for patients with sickle cell disease is largely palliative therefore adequate clinical care should include strategies which improve quality of life such as: right to housing, school, work, transportation, social activities, medical care and family support and treatment participation, which is of utmost importance [12].

Dental care for sickle cell disease patients plays an important role in the prevention of complications and in life quality improvement [12], once these patients are more susceptabale to oral infection [13]. They present increased caries risk mainly due to changes in dental structure and continuous use of medication containing sucrose. Systemic complications lead to frequent hospitalizations which are not always followed by appropriate oral hygiene [14], triggering the dental caries disease development.

The scientific literature is still scarce regarding oral problems and their consequences on the life quality of life of the sickle cell patient, and only a few studies have shown an increase in the prevalence of caries in children with this blood disorder [15-17].

Dental caries begins before the development of the clinically detectable lesion. Its multifactorial etiology derives from the interrelationship among dental surface, dietary carbohydrate fermentation, saliva and the microorganisms of the dental biofilm [18]. However, not all individuals present similar predispositions for the development of caries. There is an individual variability of the caries risk which is mainly related to diet and the number of cariogenic microorganisms present in the dental biofilm and saliva [19]. The patient's low oral hygiene levels increases the risk of caries lesion onset [20].

Saliva is a determining factor in dental caries disease development and can be defined as an aqueous fluid which moistens the oral cavity and is secreted by the salivary glands. The main saliva functions are: protect and defend the oral mucosa and teeth, form the food bolus; initiate the digestion of polysaccharides, such as starch and glycogen, regulate the oral medium $\mathrm{pH}$ through the salivar 
buffers, mucin, bicarbonate and monophosphate and perform mouth autoclisis through masticatory movements [18]. Its buffering capacity is an important resistance factor in avoiding dental caries. A reduction in salivary flow, which is usually associated with a low buffer capacity, may provoke the development of oral mucosal infections [18]. Due to the importance of saliva in relation to caries prevention, routine exams should include salivary tests in order to evaluate patients for the risk of developing the disease [18]. Since demineralization and remineralization events can cause caries disease, detecting caries as early as possible is crucial for pursuing the early stages of the disease, which based on the biological model, may allow real epidemiological data regarding the presence of incipient and active / inactive lesions. Thus it is essential to research preventive oral disease issues and improve the life quality of sickle cell disease patients. Prevention is very important in reducing the need for radical treatment and the elimination of oral infection sources. Morever acute infection treatment should be mandatory since an infection may trigger the sickle cell crisis [1].

Considering the need for adequate dental care in order to provide better life quality, the aim of the present study was to analyze the oral health conditions and caries risk factors of sickle cell disease patients.

\section{METHODS}

The present observational and sectional research was approved by the Research Ethics Committee (CEP) of the Centro Universitário Cesmac (Process n ${ }^{\circ}$ 382.870) and the participation of the volunteers authorized through signing of the Term of Free and Informed Consent (CNS 466 / 12). The sample was selected for convenience, considering 43 of the 46 patients with sickle cell disease, ranging in age from 6 to 44 years old, enrolled in the Association of People with Hemoglobinopathies of Alagoas (APHAL), a nongovernmental institution. The participants had regularly visited the institution of specific medications for the treatment of the disease.

The analysis of caries prevalence followed the criteria for caries detection and subsequent conversion to the codes of the DMFT and dmf-d indices that measure the experience of caries in the permanent and deciduous dentition, respectively [21]. The active lesions of caries, without cavitation, were included in the carious component of the DMFT and dmf-t. The examiner received theoretical and practical calibration and showed a Kappa agreement level above 0.6 with the gold standard. Patients were sitting on a portable dental chair according to biosafety standards and examinations performed under artificial lighting on a translimate Denlite $₫$ mirror (Welch Allyn, USA), and allowed to dry the teeth with gauze for 5 seconds. In order to evaluate the salivary flow of each volunteer, the stimulated saliva was collected for five minutes by chewing a paraffin wipe and the secreted volume was quantified in a disposable syringe $(20 \mathrm{~mL})$. The buffer capacity test, as recommended by Ericsson (1959) [22], was performed after mixing $1 \mathrm{~mL}$ of saliva with $3 \mathrm{~mL}$ of hydrochloric acid $(0.005 \mathrm{~N})$ in a test tube and shaken for 30 seconds. After 10 minutes, for the evaporation of carbon dioxide, the final $\mathrm{pH}$ of the solution, representative of the buffer capacity, was verified using a $\mathrm{pH}$ electrode coupled to a potentiometer 720A (Procyon do Brasil LTDA, São Paulo) 33. The classification of the salivary flow and buffer capacity of each volunteer was based on the parameters defined by Axelsson [23].

Dental biofilm accumulation was evaluated through the simplified oral hygiene index - SOHI (Greene and Vermillion, 1964) [24], examination of teeth and index surfaces: 11, 31, 16 and 26 (vestibular surface) and 36 and 46 (lingual surface) were performed. When the incisor teeth were absent, the central incisors on the opposite side of the midline were examined, and the first molars were replaced by the later, for the deciduous dentition the same procedure was performed.

The dental calculus of these teeth and surfaces were Initially analyzed, followed by biofilm presence using (Replak®, Dentisply, São Paulo) which was applied, with a clinical clamp and cotton, directly to the gingival papillae of the index teeth, allowing the solution to flow through the dental surfaces to be analyzed. The volunteers washed their mouths with water and spat to eliminate the solution residues. After the intra-oral examinations, the patients received an oral hygiene kit containing dental brush, toothpaste, floss and mouthwash for oral hygiene practice.

A structured 10 direct question- interview about the oral hygiene and diet habits of the volunteers was applied. Before data collection, 5 volunteers (about 10\% of the sample) were tested, who showed understanding about the questions asked. The researcher had been trained to behave friendly, respect the sequence of questions and use the same tone of voice for all volunteers [25]. The interview was applied individually before the 
oral examinations, in the dental office of the Association of People with Hemoglobinopathies of Alagoas (APHAL). The answers of the interview demonstrated the influence of the variables: oral hygiene and diet, in the development of dental caries disease.

Data were analyzed using the Spearman correlation test and analysis of variance (ANOVA 1 criterion) with significance level of $5 \%$, using BIOESTAT $5.0 \circledast$ software.

\section{RESULTS}

After the data collection, the sample consisted of $49 \%$ female volunteers $(n=21)$ and $51 \%$ male ( $n$ $=22$ ), who were grouped according to their ages, as follows: 6 to 12 years old $(n=8.19 \%),(N=16.37 \%)$, 20 to 26 years old $(n=12.28 \%)$ and 27 to 44 years old ( $n=7,16 \%)$, order to facilitate the discussion of the results. Following the presentation of sociodemographic data and sickle cell disease, $58.14 \%$ of the volunteers were diagnosed with sickle cell disease after 2 years old and $41.86 \%$ were diagnosed in the first two years of age.

The results concerning the prevalence of dental caries (DMFT/dmf-d), oral hygiene level (IHOS), salivary flow and buffer capacity of the volunteers are shown in graphs 1, 2 and table 01 .

After analyzing salivary parameters of the volunteers, a positive correlation between the values of salivary flow and buffer capacity (Figure 01 ). Concerning salivary conditions, by age group, it was observed that the 27 to 44 years old group presented the highest stimulated secretion of saliva per minute (ANOVA, Tukey, $p<0.05$ ) and there was no statistically significant difference between the buffer capacity values of the four age groups analyzed (ANOVA, p> 0.05). The results of caries prevalence showed a negative correlation with the buffer capacity of volunteers aged 6 to 12 years old and 20 to 26 years old, the higher the DMFT/dmf-t the lower the buffer capacity.

After the descriptive analysis of the interview data, through the Excel 2007 Program, the results have been expressed, in percentages, in figures 2, 3, 4 and 5 .

\section{DISCUSSION}

The present study demonstrated that there was no difference in the prevalence of SCD, by sex. in the Association of People with Hemoglobinopathies in
Alagoas ( $p>0.05$ ). These data confirm the unpublished survey in 2008, in the same association which showed the prevalence of $51 \%$ of male patients and $49 \%$ of female. Regarding patients' age group, a low percentage of individuals aged $27-44$ years old (16\%) can be observed, when compared to the number of individuals under 27 years old (84\%). This result may show the low life expectancy, around 42 years for men and 48 years for women, 26 of patients with sickle cell disease, which suggests a higher number of deaths in the young adult age group.

The early SCD diagnosis is essential for patients' life quality and life expectancy and the results of the present study demonstrated that $42 \%$ of the total volunteers and $100 \%$ of the volunteers who were born after 2005 had had their diagnosis of sickle cell disease in the first years of life, a fact showing that the Brazilian Ministry of Health Ordinance No. 1018 / GM, of July 1, 2005, which establishes the National Policy for Sickle Cell Disease (PNADF), thus increasing the life expectancy of individuals affected by the disease had been applied. This public health policy is justified by the fact that, currently, it is estimated that the sickle cell trait is found in $4 \%$ of the Brazilian population and that the SCD is found in approximately 25,000 to 50,000 people [26].

It is known that sickle cell disease patients, depending on the disease type, present different degrees of clinical findings, leading to a greater number of hospitalization episodes and blood transfusions, which may contribute to a greater number of oral manifestations. Factors such as the ingestion of medicinal products which alter salivary parameters together with oral hygiene deficiency, caused by frequent hospitalizations and painful crises, suggest a greater tendency to dental problems, more specifically dental caries [27].

The sample of sickle cell disease patients analyzed showed a mean DMFT/dmf-t classified as very high prevalence of caries, regardless of sex and age group. A similar result was found in the studies by Laurence et al. [17], who had also observed very high caries prevalence $(\mathrm{DMFT}=12$ ) in patients with sickle cell disease. The observation of the components of total DMFT/dmf-t revealed that more than $72 \%$ of the index was composed of the decayed and restored decayed caries teeth and the age group of 13 to 19 years old presented the highest percentage of the decayed teeth, showing the need for restorative dental treatment and / or remineralization of these volunteers. The need for 
dental care to the sickle cell disease patients analyzed also showed that in the age group with the highest caries prevalence ( 27 to 44 years old), the restored component represented less than $15 \%$ of the DMFT / dmf--t, the low demand for dental care, which can be justified by the patient's fear or seeking care impairment, as well as the the professionals' lack of preparation to provide adequate care to them.

The results found in the APHAL can not be fully compared with the data obtained in the Brazilian population, through the survey of SB Brazil 2010 [21], due to the criteria of caries diagnosis applied and the characteristics of the sample such as: volunteer's health condition and age groups analyzed. However, it can be observed that in individuals presenting good general health, in the age group index of 12 years old, the average DMFT of the city of Maceió (AL), municipality where APHAL is located, was around 2.46, demonstrationg a result 5 times lower than that found in sickle cell disease patients in the age group corresponding to 13 to 19 years old $(\mathrm{DMFT} / \mathrm{dmf}-\mathrm{t}=12.31)$, which suggests dental caries risk to sickle cell disease patients.

The application of more accurate caries detection criteria in epidemiological studies provides a real situation of the population oral health conditions, since it includes the teeth presenting caries lesions without cavitation as decayed teeth. Such a need for improved caries detection justifies the application of the ICDAS - International Caries Detection Assessment System [20] criteria used in the present research and the conversion of its components to the globally accepted DMFT/dmf-d index [21].

Oral hygiene analysis showed that the volunteers presented regular oral hygiene, regardless of the age group, although they reported brushing their teeth 2 or 3 times a day in $74 \%$ of the responses, flossing 1 to 3 times a day in $42 \%$ of the answers and cleaning the tongue 1 to more than 3 times a day in $86 \%$ of the answers. The knowledge about oral hygiene expressed by the participants demonstrates a hostile clinical reality, which can be represented by the accumulation of biofilm and dental calculus presented by th $\mathrm{SOHI}$ index scores applied.

Dental biofilm, among the determinants of caries disease, presents more than 500 different bacterial species, and some of them, such as s. mutans, s sobrinus, lactobacilli and actinomyces, are involved with the dissolution of dental enamel through carbohydrate metabolism and acid production [28]. Thus, the proper removal of dental biofilm is of great importance in the prevention and maintenance of oral health of the SCD patients, since their health is impaired by the hematological disease.

The patients presented a mean salivary flow, considered hyposalivation and low buffer capacity, which can be interpreted as risk factors for dental caries, since saliva is an important protective and modulating agent of dental tissues against the development of dental caries [23]. Regarding age groups and the salivary parameters, it was observed that, even in the 020 to 26 years and 27 to 44 years groups who presented a normal salivary flow classification, the salivation levels were borderline (around $1 \mathrm{~mL} / \mathrm{min}$ ), which is a concern regarding washing of food debris and removal of dental biofilm, which may classify patients as dental caries risk group.

Regarding the salivary flow and the buffer capacity of the volunteers, a positive relationship between them was demonstrated, showing that patients $w$ higher levels of stimulated salivary secretion determined higher values of oral $\mathrm{pH}$, corresponding to their oral acidity neutralization abilities. Salivary factors such as carbonic acid bicarbonate and phosphate system buffers provide balance of oral $\mathrm{pH}$ and allow the maintenance of mineral integrity in the structure of dental tissues [28].

The salivary parameters presented by SCD patients show the need for salivary stimulation media to adequately protect and prevent oral diseases, since they frequently make use of pain killers, tranquillizers, sedatives, musculoskeletal relaxants, antidepressants, opioids, among others, which may accentuate the reduction of the salivary flow and buffer capacity, favoring the development of cariogenic microorganisms in the oral cavity such as S mutans [28].

The results of the present study showed that volunteers aged 6 to 12 years old and 20 to 26 years have presented the highest levels of buffering of oral acids and the lowest values of the DMFT-dmf-t index (negative correlation), which emphasizes the importance of buffer capacity of saliva as a means of mineral balance in the dental structure and an important protection against dental caries.

The interview responses showed, in general, that the volunteers present risks of frequent reduction of salivary flow and buffer capacity, due to the use of medications during the pain crises, which act on the sympathetic and parasympathetic nervous system and 
can provide hyposalivation and / or xerostomia exposing them to caries risk and significantly interfering in the individuals' quality of life.

The demand for dental care and its respective reason were the objectives of two interview questions and the answers showed that the majority of SCD patients reported having been to the dentist in less than a 1 year period and the reason for the appointment was invasive dental treatment (restorations, exodontia or endodontia). These data show the need for professionals and dental care services training in order to provide adequate care of these patients, considering their great need. The present study highlights patients' needs regarding caries indices, oral hygiene levels, salivary flow, buffer capacity and levels of knowledge about diet and oral hygiene.

The answers of the two questions regarding the diet consumed showed that SCD patients presented a high intake percentage of fermentable carbohydrates (cariogenic foods) between the main meals, and all the interviewees reported that they had not received dietary advice from the dentist. This is especially important due to the general health risks an inadequate diet can cause, as well as greater exposure of dental tissues to constant acid challenges. The SCD patient, objective of the present research, needs constant educational / preventive approach. The risk of caries due to the frequent consumption of fermentable carbohydrates and inadequate dental brushing, especially at night may lead to dental demineralization due to increased oral exposure to acidic challenges once salivary flow is reduced during the sleep period [28].

The role of the dentist in the development of general health is undeniable once advice on noncariogenic foods can provide a healthy oral environment as well as a better quality of life. The lack of answers related to dental counseling by the dentist can reveal the lack of concern of the professionals regarding the educational and preventive aspects of dental caries disease, a fact that may increase the risk of caries development in SCD patients.

Self-care, defined as the set of an individual preventing, controlling, diagnosing and treating attitudes, promotes health actions and serves as an important

\section{REFERENCES}

1. Ramakrishna Y. Dental considerations in the management of children suffering from sickle cell disease: a case report. J Indian strategy to control dental caries in this population with hematological disease [29]. Among some actions are the control of dental biofilm through the daily practice of brushing with fluoride dentifrice and the use of dental floss, which are the most efficient methods in order to reduce the biofilm and restore small mineral losses with the action of fluoride [30].

Specific preventive and therapeutic strategies should be developed for dental care for SCD patients, regarding periodicity appointments, antimicrobial and fluoride application, professional mechanical control, oral health education, diet advice, hygiene guidance, caries cavity excavation, through atraumatic techniques, and consequent restorations with suitable dental materials, as well as the removal of infection foci and presumed sources of bacteremia.

\section{CONCLUSION}

The patients have presented a very high prevalence of caries, with the predominance of decayed teeth. The salivary parameters analyzed and the level of knowledge on oral hygiene and cariogenic diet demonstrated that patients with sickle cell disease belong to a group at risk of developing dental caries, requiring a frequent educationalpreventive approach on the importance of oral health for the quality of life.

\section{SPECIAL THANKS}

The presidency of the Association of People with Hemoglobinopathies of Alagoas (APHAL), to the volunteers and the Programa Semente of Scientific Initiation (PSICPost Graduation of the University Center (ESMAC) that made the accomplishment of this research possible.

\section{Collaborators}

MLBB MEDEIROS, LL MENDES and SLP LOPES, data collect. EL ARAÚJO, sample selection and recruitment. ICG MENDONÇA, spelling review. EN MEDEIROS, data tabulation. TC CAVALCANTI, statistical analysis. NB SANTOS, leader.

Soc Pedod Prevent Dent. 2007 Sep:140-143. doi: 10.4103/09704388.36566

2. Mendes PHC, Fonseca NGF, Martelli DRB, Bonan PRF, Almeida LKY, Melo LAm et al. Orofacial manifestations in patients with sickle cell anemia. Rev Quintessence. 2011 Sep;42(8):701-9. 
3. Brasil. Ministério da Saúde. Secretaria de Atenção à Saúde. Departamento de Atenção Básica. Manual de Condutas Básicas na Doença Falciforme. Brasília: Ministério da Saúde ; 2009.

4. Botelho DS, Vergne AA, Bittencourt S, Ribeiro EDP. Systemic profile and clinical dental procedures in patients with sickle cell disease. Int J Dent. 2009:8:28-35.

5. Konotey-Ahula FI. The sickle cell disease. Arch Intern Med. 1974;133:611-9.

6. Serjeant GR. Geography and the clinical picture of sickle cell disease. An overview. Ann NY Acad Sci. 1989;565:109-19. doi: 10.1111/j.1749-6632.1989.tb24157.x

7. Benerjee AK. Safe surgery in sickle cell disease. $\mathrm{Br} J$ Surg. 1991;78:516-7.

8. Brasil. Agência Nacional de Vigilância Sanitária. Manual de diagnóstico e tratamento de doenças falciformes. Brasília: ANVISA; 2002 [citado 2011 Ago 19]. Disponível em: <http:// bvsms.saude.gov.br/bvs/publicacoes/anvisa/diagnostico.pdf>.

9. Santos SJ, Mesquita DA, Rocha JR. A atuação do psicólogo da saúde no tratamento à pessoa com doença falciforme em Alagoas. Cad Grad-Ciências Biol Saúde. 2013;1(3):35-56.

10. Rocknagel DL. The genetics of sickle cell anemia and related syndromes. Arch Intern Med. 1974;133:595-606.

11. Ramalho AS, Magna LA, de Paiva e Silva RB. A portaria MS $n^{\circ}$ 822/01 e a triagem neonatal das hemoglobinopatias. Rev Bras Hematol Hemoter. 2002;24(4):244-50. doi: 10.1590/S151684842002000400002

12. da Fonseca M, Oueis HS, Casamassimo PS. Sickle cell anemia: a review for the pediatric dentist. Pediatr Dent. 2007 MarApr;29(2):159-69.

13. Taylor LB, Nowak AJ, Giller RH, Casamassimo PS. Sickle cell anemia: a review of the dental concerns and a retrospective study of dental and bony changes. Spec Care Dentist. 1995 JanFeb;15(1):38-42. doi: 10.1111/j.1754-4505.1995.tb00469.x

14. Brasil. Ministério da Saúde. Secretaria de Atenção à Saúde. Departamento de Atenção Especializada. Manual de Educação em Saúde; 2008 [citado 2011 Ago 19]. Disponível em: <http:// bvsms.saude.gov.br/bvs/publicacoes/manual_educacao_saude_ volume1.pdf>

15. Soares FF, Rossi TRA, Brito MGS, Vianna MIP, Cangussu MCT. Condições de saúde bucal e fatores sociodemográficos de crianças de 6 a 96 meses com doença falciforme no Estado da Bahia. Rev Odontol UNESP. 2010 mar/abr; 39(2):115-121.

16. Alves e Luna AC, Rodrigues MJ, Menezes VA, Marques KMG, Santos FA dos. Caries prevalence and socioeconomic factors in children with sickle cell anemia. Braz Oral Res. 2012 JanFeb;26(1):43-9. doi: 10.1590/S1806-83242012000100008

17. Laurence B, George D, Woods D, Shosanya A, Katz RV, Lanzkron $S$, et al. The association between sickle cell disease and dental caries in African Americans. Spec Care Dentist. 2006;26(3):95100. doi: 10.1111/j.1754-4505.2006.tb01430.x

18. Edgar WM, O'Mullane DM. Saliva and dental health. Clinical implications of saliva: report of a consensus meeting. Br Dent J. 1990;169(3-4):96-8

19. Van Houte J. Microbiological predictors of caries risk. Adv Dent Res. 1993 Aug; 7(2):87-96

20. Ismail Al, Sohn W, Tellez M, Willem JM, Betz J, Lepkowski J. Risk indicators for Dental Caries Using the International Caries Detection and assessment System (ICDAS). Community Dent Oral Epidemiol. 2008;36:55-68. doi: 10.1111/j.16000528.2006.00369x

21. Brasil. Ministério da Sáude. Secretaria de Atenção à Saúde Secretaria de Vigilância em Saúde. Departamento de Atenção Básica. SB Brasil 2010. Brasília: Ministério da Sáude; 2011.

22. Son Y. Clinical investigation of the salivary buffering action. Acta Odontol Scand.1959:(97):131-165. doi: 10.3109/00016355908993928

23. Axelsson P. Diagnosis and risk prediction of dental caries Germany: Quintessence Pub Co; 2000

24. Greene JC, Vermillion JR. The simplified oral hygiene index. J Am Dent Assoc. 1964;68:7-13. doi: 10.14219/jada. archive. 1964.0034

25. Bowling A. Model of questionnaire administration can have serious effects on data quality. J Public Health 2005;27:281:291. doi: 10.1093/pubmed/fdi031

26. Silveira EL, Silla LMR, Krug BC, Amaral KM. Doença falciforme. protocolos clínicos e diretrizes terapêuticas. São Leopoldo: Editora Pallotti; 2010

27. Hosni JS, Fonseca MS, da Silva LCP, Cruz RA. Protocolo de atendimento odontológico para paciente com anemia falciforme. Arq Bras Odontol. 2008;4(2):104-112.

28. Macpherson P. The role of saliva in oral health and disease. Dental Nursing. 20130ct;9(10):568-574

29. Gomes VE, Silva DD da. A importância do controle de placa dental na clínica odontológica. Arq Odontol. 2010 Jan-Mar; 46(1): 22-27.

30. Al-Ahmad A, Roth D, Wolkewitz M, Wiedmann-Al_Ahmad M Follo $\mathrm{M}$, Ratka-Krüger $\mathrm{P}$, et al. Change in diet and oral hygiene over an 8-week period: effects on oral health and oral biofilm. Clin Oral Invest. 2010;14:391-3. doi: 10.1007/S00784-0090318-9.

Received on: 17/12/2018

Final version resubmitted on: 18/4/2018

Approved on: 11/8/2018 